\title{
POLA PENGEMBANGAN KEBERBAKATAN DAN PEMBENTUKAN KEDISIPLINAN ANAK
}

\author{
Tahrir
}

Fakultas Psikologi Universitas Islam Bandung

Giftedness and discipline are important basic foundation for children to prepare their future. Thus, the development of giftedness and altering behavior with self disciplined regulation needs to be counted for by parents and teachers. Focusing on nurturing giftedness was considered important that children can prepare themselves to be professional individuals who know their strengths and weaknesses to face all aspects in life. In the other hand, discipline and self regulatory were set to prepare those children to have responsibilities and professional ethos both at work life and in personal life. Parents and teacher in this case need to provide time and design a systematic plan to develop their potential. An effective model for this purpose is a giftedness development and self regulatory training which were designed according to the principal of children's development.

Keywords: Giftedness development model and children's self regulatory training.

\section{Pendahuluan}

Allah Swt. menciptakan manusia dengan tujuan yang sangat mulia, yaitu untuk menjadi khalifah di muka bumi. Untuk tujuan mulia itu, setiap anak yang dilahirkan dibekali dengan berbagai potensi keberbakatan sebagai perangkat yang disiapkan-Nya sejak dini. Keberbakatan yang telah dimiliki oleh setiap anak merupakan suatu modal dasar yang sangat potensial untuk mengembangkan dan mengaktualisasikan diri dalam kehidupannya. Anak yang dapat mengembangkan keberbakatannya dengan baik akan mampu mengembangkan dirinya sesuai dengan harapan diri dan orang tuanya.

Dalam proses perjalanan kehidupannya hingga anak itu menjadi dewasa, tidak jarang diantara mereka yang ada yang tidak mengenali keberbakatan diri yang sebenarnya.
Akhirnya ia menjalani kehidupan dengan apa adanya, yang hanya menggantungkan pada nasib. Hal ini terbukti dengan seringnya ditemukan remaja yang mengatakan bahwa dirinya tidak memiliki keberbakatan apa-apa. Mereka bingung untuk mengidentifikasi keberbakatan dirinya, akibatnya mereka sering menghadapi kesulitan untuk mengaktualisasikan diri sesuai dengan keinginannya.

Ketidakmampuan mereka untuk mengenali keberbakatan dirinya adalah masalah besar yang membutuhkan usaha-usaha serius dari banyak pihak untuk memecahkannya terutama orang tua dan pendidik. Jika keadaan seperti ini dibiarkan terus berlanjut, maka akan sangat merugikan bagi generasi-generasi penerus berikutnya dan sama halnya dengan membiarkan anak berada dalam masalah. 
Banyak faktor yang dapat menyebabkan seorang anak tidak mampu mengetahui keberbakatan dirinya seperti peran orang tua serta peran pendidik yang tidak optimal dalam mengasuh dan mendidik anak didiknya. Disamping itu juga peran kontrol dari masyarakat yang kurang optimal terhadap pengembangan bakat generasi mudanya. Sedikit banyaknya, dari masyarakat ada yang memberikan penilaian terhadap apa yang dilakukan anak-anak apakah perilaku itu sesuai dengan keberbakatannya atau tidak.

Pada dasarnya keberbakatan anak adalah bukan suatu hal yang bersifat statis, tapi ia bersifat dinamis. Keberbakatan seorang anak dapat ditelusuri, digali, dan dikembangkan, sehingga dapat dijadikan modal dasar dalam menghadapi suatu kehidupan yang penuh tantangan, hambatan, dan rintangan. Oleh karena itu orang tua dan para pendidik tidak perlu merasa takut jika seorang anak mengatakan bahwa dirinya tidak mengetahui dan tidak memiliki keberbakatan. Di sinilah peran orang tua untuk membantu mengembangkan keberbakatan anak hingga sang anak mampu mengembangkan keberbakatannya secara optimal. Untuk mencapai hal tersebut mereka harus dibimbing dan diarahkan secara kontinyu semenjak dini, sehingga pada saat tertentu mampu mengetahui apa keberbakatan dirinya yang sebenarnya.

Proses perkembangan manusia terjadi sejak masa konsepsi sampai akhirnya meninggal dunia. Dalam proses perkembangannya, manusia melewati fase-fase tertentu, seperti fase pranatal, natal, pascanatal, anak, remaja, dewasa, hingga usia lanjut, dan akhirnya meninggal dunia.

Pada setiap fase terjadi perubahan dan perkembangan, baik fisik maupun psikis, unsur biologis dan unsur mental, sesuai dengan fasefase perkembangan ini juga setiap anak mengalami perkembangan keberbakatannya. Proses perkembangan keberbakatan setiap anak berbeda-beda sesuai potensi yang dimilikinya, rangsang yang diterima dari lingkungan, dan usaha dirinya.

Proses perkembangan keberbakatan yang baik itu terjadi jika pengembangan itu sesuai dengan fase-fase perkembangan anak. Karena pada setiap fase perkembangannya anak memiliki tugas-tugas tertentu dan memiliki kemampuan-kemampuan tertentu sesuai dengan potensi yang dimilikinya. Suatu pengembangan akan menjadi masalah jika seorang anak dipaksakan untuk mengalami perkembangan tertentu yang belum tentu sesuai dengan kemampuan dirinya. Demikain juga seseorang dikatakan terlambat jika upaya pengembangan keberbakatan dirinya tidak sesuai dengan masa perkembangannya.

Sebenarnya, seorang anak tidak cukup hanya mengandalkan keberbakatan diri dalam mengaktualisasikan dirinya. Keberbakatan tidak dapat dimanfaatkan secara maksimal jika tidak diikuti dengan aspek lain, yaitu kedisiplinan. Dengan kedisiplinan yang tinggi individu akan memiliki tanggung jawab, minat, motivasi yang tinggi dalam menjalankan seluruh aktivitasnya. Pola-pola perilaku masyarakat Indonesia yang kurang memiliki sikap disiplin tinggi dalam segala aktivitasnya, 
merupakan fenomena yang umum terjadi. Kenyataan ini juga nampak sekali pada anakanak kita. Tidak sedikit dari mereka yang sulit diatur dan terkadang mereka berbuat maunya sendiri.

Sesungguhnya, menanamkan sikap disiplin pada anak itu adalah bukan pekerjaan yang tidak mudah. Ini membutuhkan energi yang ekstra dan bimbingan yang intensif dalam waktu yang relatif lama. Ternyata, banyak faktor yang menyebabkan anak-anak tidak memiliki sikap disiplin yang cukup, baik faktor lingkungan keluarga, lingkungan sekolah, dan lingkungan masyarakat umum. Disamping itu, metode yang digunakan juga tidak dapat diabaikan, dan yang lebih penting lagi adalah kondisi psikologis anak. Menurut Hurlock (1987), kedisiplinan berkembang searah dengan perkembangan usia. Semakin matang usia dan kondisi psikologis anak, semakin matang pola kedisiplinannya. Akan tetapi sebagai petunjuk, pengarah, dan penguat, maka bimbingan dari lingkungan sangat dibutuhkan dalam menanamkan kedisiplinan anak.

\section{Pola Pengembangan Keberbakatan Anak}

Kata pengembangan dalam psikologi merupakan suatu istilah yang mengandung makna serangkaian perubahan secara progresif yang mengacu pada proses kematangan dan pengalaman. Sedangkan keberbakatan merupakan warisan genetik yang berkembangan mengikuti hukum perkembangan. Menurut Gardner (2003) keberbakatan adalah tanda potensi biopsikologis yang berkembang dengan cepat dalam bidang apa pun. Dengan demikian maka pola pengembangan keberbakatan anak berarti suatu desain yang dikemas untuk mengembangkan bakat anak dalam berbagai bidang keahlian berdasarkan proses-proses kematangan dan pengalaman yang tersistem.

Menurut Gardner \& Walter (2003) keberbakatan manusia tidak terbatas jumlahnya. Akan tetapi secara garis besar dapat dibedakan dalam tujuh tipe keberbakatan utama yaitu: musik, gerak-badan, logika-matematik, linguistik, ruang, antar pribadi atau sosial, dan inter pribadi.

Walaupun keberbakatan merupakan bagian dari warisan genetik, tapi dalam proses perkembangannya tetap membutuhkan sarana atau rangsangan-rangsangan lain yang membantu kelancaran perkembangannya. Saranasarana tersebut bisa berupa bimbingan, pelatihan, kondisi kesehatan, dan kondisi lingkungan secara umum. Dalam hal ini maka peran orang tua, para guru, dan para pendidik sangat dibutuhkan untuk membantu proses perkembangan keberbakatan anak agar sesuai dengan apa yang diharapkan.

Namun demikian, keterlibatan orang tua dan para pendidik dalam membantu perkembangan keberbakatan anak menunjukan hasil yang tidak maksimal. Hal ini terjadi karena pola yang mereka gunakan tidak memperhatikan faktor-faktor penting yang ada pada anak dan lingkungan. Pola yang mereka gunakan cenderung memaksakan kehendak, anak dipaksakan untuk mengikuti segala yang mereka inginkan tanpa memperhatikan keinginan anak juga tidak disesuaikan dengan 
kesiapan psikologis anak. Standar pencapaian keberhasilan yang ingin diraih juga tidak sesuai dengan potensi psikologisnya, mereka memaksakan agar anak-anaknya dapat berhasil seperti mereka. Bahkan tidak sedikit yang mengharapkan agar anak-anak lebih baik dari orang tuanya.

Di samping itu juga suasana dan lingkungan tidak disesuaikan dengan kondisi dan kecenderungan anak. Orang tua dan para pendidik kurang memperhatikan terciptanya lingkungan yang menarik bagi anak-anak serta tidak memberikan peralatan-peralatan yang sangat dibutuhkan anak dalam mengembangkan keberbakatan anak. Padahal sebetulnya, lingkungan dan sarana bermain adalah perangkat yang sangat membantu dalam proses pengembangan keberbakatan anak.

Dengan demikian, pola yang efektif dalam mengembangkan keberbakatan anak adalah yang memperhatikan faktor-faktor berikut; yaitu : kondisi psikologis anak, kondisi lingkungan, kondisi orang tua dan pendidik.

\section{Kondisi Psikologis Anak.}

Kondisi psikologis yang harus diperhatikan oleh orang tua dan para pendidik adalah kondisi perkembangan anak. Dengan mengacu konsep perkembangan, maka ada tiga hal penting yang perlu diperhatikan dalam proses pengembangan keberbakatan anak:

a. Pemahaman tentang prinsip-prinsip perkembangan.

Yaitu perkembangan melibatkan perubahan dan perkembangan awal lebih kritis ketimbang perkembangan selanjutnya.
Perkembangan merupakan suatu perubahan dari hasil proses kematangan dan belajar, polanya memiliki karakteristik sama yang dapat diramalkan, dan adanya perbedaan individual. Periode pola perkembangan berlangsung secara berkesinambungan, dan pada setiap periodenya terdapat harapan-harapan sosial.

Prinsip-prinsip perkembangan dalam mengembangkan keberbakatan anak yang perlu diperhatikan oleh para pendidik adalah: pertama, hal apa saja yang diharapkan dari anak untuk mengembangkan keberbakatannya, pada usia berapa kirakira munculnya berbagai pola perilaku yang berkaitan erat dengan keberbakatan, dan kapan pola itu diganti dengan pola yang lainnya; kedua, pedoman penilaian dan skala pengukuran macam apa untuk mendeteksi perkembangan keberbakatan anak; dan ketiga, untuk menyusun pola bimbingan yang mampu mengembangkan keberbakatannya dengan baik.

b. Pemahaman tugas-tugas perkembangan Yaitu, tugas yang muncul pada periode tertentu dari kehidupan individu. Jika tugas ini berhasil akan menimbulkan keseimbangan psikologis dan membawa kearah keberhasilan dalam tugas-tugas berikutnya. Tujuan tugas perkembangan adalah petunjuk bagi individu untuk berbuat sesuai dengan harapan masyarakat, memberikan motivasi bagi individu agar dapat melakukan sesuatu yang sesuai dengan harapan masyarakat, dan menunjukan bagi 
individu apa yang akan dihadapi dan tindakan apa yang diharapkan dari mereka. Pemahaman tugas-tugas perkembangan bermanfaat bagi orang tua dan para pendidik dalam mengembangkan keberbakatan anak adalah: pertama, sebagai pedoman untuk membantu hal apa saja yang dapat dilakukan anak untuk mengembangkan keberbakatan pada usia-usia tertentu. Kedua, menunjukkan pada orang tua dan para pendidik tentang perilaku apa yang dapat diharapkan anak pada masa yang akan datang dalam mengembangkan keberbakatannya.

c. Pemahaman tentang kondisi-kondisi yang membahayakan tugas perkembangan.

Karena tugas-tugas perkembangan memiliki peran penting dalam menentukan arah perkembangan yang normal, maka apa pun yang menghalangi penguasaan sesuatu dapat dianggap sebagai bahaya potensial. Bahaya potensial dalam tugas perkembangan anak adalah: harapan-harapan yang kurang tepat dari masyarakat terhadap individu, melangkahi tahap tertentu dalam perkembangan.

Pemahaman akan prinsip-prinsip perkembangan dan kondisi yang mempengaruhi perkembangan anak dapat menuntun kita untuk mengetahui kapan saat anak telah matang baik secara mental maupun fisik untuk menerima seluruh materi bimbingan dan kriteria kesiapan belajar merupakan karakteristik spesifik kematangan mental anak. Dengan mengetahuinya waktu kesiapan belajar anak dapat merangsang dan membangkitkan inspirasi kita untuk memberikan bantuan yang tepat pada anak agar mereka dapat merealisasikan dirinya dengan baik. Pemahaman tentang prinsipprinsip dan kondisi yang mempengaruhi perkembangan anak juga dapat menghindarkan kita dari kesalahan dalam memberikan bimbingan.

\section{Kondisi Lingkungan}

Di samping pemahaman tentang ketiga hal diatas, orang tua dan para pendidik harus mampu menciptakan kondisi yang mendukung dalam proses pengembangan keberbakatan anaknya. Kondisi tersebut diciptakan sedemikian rupa agar anak-anak betah dan mendapatkan kenyamanan yang maksimal. Menurut Dryden \& Vos (2002) kondisi yang paling baik untuk merangsang terjadinya pengembangan keberbakatan yang baik adalah keterlibatan langsung atau penjelajahan objek dan suasana yang menyenangkan.

Keterlibatan langsung atau penjelajahan objek yang dimaksud adalah melibatkan anak secara langsung terhadap objek-objek materi. Anak-anak tidak hanya diberi materi yang bersifat teoritis atau konseptual, karena pada usia ini kemampuan anak untuk memahami konsep masih sangat minim dan justru sebaliknya mereka akan sangat mudah menerima dan memahami segala materi jika di tunjukkan langsung pada objeknya. Seperti telah dikemukakan oleh Piaget (1976) bahwa kemampuan kognisi anak berada pada tahap operasional kongkrit maksudnya bahwa kemampuan anak untuk memikirkan sesuatu adalah baru pada hal-hal yang bersifat kongkrit. 
Karena kemampuan kognisinya baru pada tahap ini maka seorang anak akan menunjukkan minat yang tinggi jika seluruh apa yang ia terima dapat dilihat dan dipegang langsung. Seorang anak akan menunjukkan minat terhadap objek penjelajahan yang sesuai dengan keinginan dirinya. Kecenderungan respon anak terhadap objek materi juga dapat menggambarkan tentang arah keberbakatan anak di masa yang akan datang. Orang tua dan para pendidik juga dapat meramalkan ke arah mana keberbakatan anaknya berdasarkan kecenderungan minat anak terhadap objek yang mereka inginkan.

Sementara suasana yang menyenangkan menurut Dryden \& Vos (2002) dapat diciptakan oleh orang tua dan para pendidik atau juga oleh anak didiknya sendiri. Orang tua dan para pendidik dapat membuat suasana yang menyenangkan dengan cara menghias ruangan sedemikian rupa, memilih tempat-tempat rekreasi dan sebagainya. Orang tua dan para pendidik juga harus memberikan kesempatan pada anak untuk memilih dan menentukan tempat belajarnya serta harus memberikan kesempatan kepada anaknya untuk menghias ruangan sesuai dengan selera mereka. Kesempatan untuk mengungkapkan kreasi dalam menghias ruangan bagi anak sangat bermanfaat untuk membantu mereka mengembangkan keberbakatan mereka. Sebab dengan diberinya kesempatan yang luas menjadikan anak mampu mengekpresikan dirinya yang aslinya dan ekpresi yang diinginkannya.

Suasana lain yang sangat baik dalam pengembangan keberbakatan adalah dimana seorang anak diberikan kebebasan untuk mengemukakan pendapatnya mengenai objekobjek materi. Orang tua dan para pendidik tidak diperbolehkan memotong atau menyalahkan terhadap seluruh alasan yang dikemukakan oleh anak sebelum mereka selesai dalam mengemukakannya. Perasaan bersalah dan perasaan bahwa dirinya tidak mampu serta perasaan frustrasi akan muncul pada seorang anak jika pembicaraan sering dipotong dan disalahkan.

3. Kondisi Orang Tua dan Pendidik.

Orang tua dan pendidik mempunyai peran yang sangat besar dalam mengembangkan keberbakatan anak. Orang tua adalah pembimbing pertama bagi anak yang mengenalkan tentang segala hal yang ada di dunia ini. Dengan orang tua seorang anak dapat mengenal siapa dirinya, orang lain, bendabenda di sekelilingnya, sehingga pada saatnya nanti anak-anak mengerti apa keberbakatan dirinya dan telah berkembang. Orang tua dapat memberikan dorongan atau motivasi kepada anak-anaknya agar mereka selalu memiliki semangat yang tinggi untuk mengikuti proses bimbingan yang diberikan orang tuanya. Orang tua juga dapat memberikan contoh-contoh tertentu yang bermanfaat bagi anak untuk diimitasikan sehingga pada saatnya nanti dapat mandiri dengan keberbakatan dirinya.

Sementara para pendidik adalah orang tua kedua yang diberi kepercayaan untuk melanjutkan bimbingan bagi sang anak. Sebagai orang kedua pendidik juga memiliki peran yang sama pentingnya bagi pengembangan keberbakatan anak, mereka akan melanjutkan 
bimbingan yang intensif setelah anak-anak dilepas oleh orang tuanya. Para pendidik dapat melakukan fungsi orang tua juga dapat melakukan fungsi kontrol terhadap proses pengembangan keberbakatan anak, pendidik dapat mengarahkan kepada anak-anak bagaimana cara ana-anak seusianya yang telah mampu mengembangkan keberbakatannya dengan baik.

Karena sangat pentingnya peran orang tua dan para pendidik dalam pengembangan keberbakatan anak, maka seluruh apa yang mereka perbuat harus didasarkan pada kondisikondisi yang dapat menunjang terhadap pengembangan keberbakatan anak-anaknya. Adapun kondisi-kondisi yang sangat mendukung suksesnya pengembangan keberbakatan anak adalah:

a. Memberikan kebebasan bereksplorasi Orang tua dan pendidik harus memberikan kesempatan yang luas pada anaknya untuk berekplorasi, seorang anak harus diberi kesempatan untuk mengemukakan pendapatnya, menata ruangan sesuai dengan keinginannya, dan memilih permainan yang sesuai dengan keinginannya. Kebebasan berekplorasi sangat positif bagi anak untuk menjajagi keberbakatanya sehingga akhirnya mereka dapat menemukan keberbakatan dirinya. Pembatasan bereksplorasi terhadap anak berarti membatasi kesempatannya untuk mengembangkan dirinya sesuai dengan keinginannya, padahal keinginan-keinginan tertentu bagi anak merupakan ekpresi dari keberbakatan dirinya. b. Memberikan waktu-waktu khusus untuk bermain

Waktu bermain sangat penting bagi anak, akan tetapi ada waktu-waktu tertentu yang sangat tidak mendukung terhadap berkembangnya keberbakatan anak bahkan dapat membahayakan. Waktu ketika anak mengatakan telah bosan bermain, waktu seorang anak harus tidur siang atau malam juga tidak dapat dipaksakan oleh orang tua dan pendidik untuk membimbing anaknya. Oleh karena itu orang tua dan para pendidik harus peka terhadap kebutuhan waktu bermain anak-anaknya, sehingga dapat mengetahui kapan saat yang terbaik untuk mengembangkan keberbakatan anaknya.

c. Memberikan dorongan

Dorongan atau motivasi terhadap anak untuk dapat melakukan sesuatu adalah sangat penting untuk membantu pengembangan keberbakatan anak. Dengan dorongan-dorongan tertentu seorang anak dapat merasa termotivasi dan dapat menimbulkan kepercayaan diri mereka dalam melakukan sesuatu. Akan tetapi orang tua dan pendidik juga harus berhati-hati terhadap dorongan-dorongan yang dapat menimbulkan motivasi anak menurun yaitu dorongan yang mengarahkan agar anak memiliki prestasi yang sama dengan teman-temannya. Dorongan ini dapat menimbulkan kekesalan bagi anak yang tidak memiliki kemampuan yang sama dengan tenam-temannya sehingga membuat dirinya merasa kesal dan tidak dihargai. 
d. Memberikan keluasan berkhayal

Menghayal bagi seorang anak memiliki nilai yang sangat positif, dengan berhayal seorang anak dapat mengembangkan kemampuan daya bayang ruang, bahasa, pola pikir atau logikanya. Akan tetapi tidak sedikit diantara orang tua dan para pendidik yang berpandangan bahwa menghayal hanya memboroskan waktu dan menjadi sumber gagasan yang tidak realistis.

f. Memberikan peralatan bermain

Permainan adalah dunia nyata bagi seorang anak, bahkan segala apa yang ada di dunia ini bagi mereka haruslah dijadikan permainan. Orang tua dan pendidik dalam hal ini bertugas memberikan jenis-jenis permainan yang sesuai dengan kodrat kemanusiaannya agar anak-anak dapat mengembangkan keberbakatannya sesuai dengan kodrat dirinya. Jenis-jenis permainan yang diberikan juga harus yang dapat menarik minat anak dan kalau bisa yang sesuai dengan keinginan mereka. Dari bentuk-bentuk permainannya dan pola-pola permainannya orang tua dan pendidik yang peka dapat menemukan dan sekaligus mengembangkan keberbakatan anaknya.

g. Memberikan perlindungan yang tidak membatasi anak

Orang tua dan pendidik yang terlalu membatasi atau terlalu memberikan kebebasan terhadap anak dapat berakibat buruk terhadap pengembangan keberbakatan anaknya. Pembatasan terhadap perilaku akan berarti pembatasan terhadap kesempatan anak dalam mengembangkan dirinya. Akan tetapi kebebasan yang berlebihan juga mengakibatkan anak tidak dapat dikendalikan dan atau brutal. Oleh karena itu perlu bagi orang tua dan pendidik untuk dapat mengatur perlindungan yang mereka berikan sehingga dapat mendukung pengembangan keberbakatan anak-anaknya.

\section{Pola Pembentukan Kedisiplinan Anak}

Konsep populer dari disiplin menurut Hurlock (1978) adalah sama dengan hukuman. Dengan konsep ini disiplin digunakan hanya bila anak melanggar peraturan dan perintah yang diberikan oleh orang tua, orang dewasa, guru atau siapa saja yang berwenang mengatur kehidupan masyarakat, tempat anak tinggal. Tujuan seluruh disiplin menurut Hurlock (1978) adalah membentuk perilaku sedemikian rupa hingga ia akan sesuai dengan peran-peran yang diterapkan kelompok budaya, tempat individu itu diidentifikasikan.

Kedisiplinan berkembang dan terbentuk dari hasil belajar. Kedisiplinan anak tidak akan terbentuk dengan sendirinya tanpa ada campur tangan dari orang tua dan lingkungan, akan tetapi kedisiplinan itu terbentuk dari hasil internalisasi terhadap seluruh aturan-aturan yang diberikan oleh orang tua, masyarakat, dan dari hasil kemampuan atau potensi dari dalam dirinya sendiri.

Orang tua dan lingkungan secara umum memiliki andil yang sangat penting dalam pembentukan kedisiplinan anak melalui pembelajaran, bimbingan dan latihan. Pembentuk- 
an kedisiplinan anak dari usia 0-6 tahun lebih besar dari bimbingan kedua orang tuanya melalui pemberian kasih sayang yang cukup, dengan memberikan sikap tegas, jelas, dan sikap lemah lembut. Seperti disiplin pola makan, pola tidur, pola buang air besar dan kecil.

Seorang anak memperoleh pola kedisiplinan ini berasal dari pelatihan dan bimbingan dari orang tua mereka selama berada dalam pangkuannya. Sedangkan peran guru dalam pembentukan kedisiplinan anak disamping sebagai pembimbing dan pelatih juga sebagai pengontrol sosial terhadap perilaku kedisiplinan anak di lingkungannya apakah kedisiplinan mereka sudah sesuai dengan harapan-harapan lingkungan sosialnya sebab kedisiplinan adalah bukan hanya untuk dirinya sendiri tapi juga untuk orang lain.

Di samping akibat faktor belajar dan pelatihan kedisiplinan juga berkembang sesuai dengan perkembangan psikologis anak. Kedisiplinan akan berkembangan sesuai dengan perkembangan nalar atau kognisi. Semakin matang kognisi seorang anak maka akan semakin baik pula penilaian dan terhadap aturan-aturan lingkungan, semakin matang kognisi akan juga akan semakin baik juga kemampuan mereka dalam memahami arti disiplin bagi dirinya dan bagi orang lain hingga akhirnya mereka mampu menghayati arti kedisiplinan bagi dirinya dalam menjalani kehidupan bermasyarakat.

Menurut Hurlock (1978) pola pembentukan kedisiplinan anak ada tiga cara yaitu pola otoriter, pola demokrasi, dan pola persimif.

\section{Pola Otoriter}

Cara peraturan dan pengaturan yang keras untuk memaksakan perilaku yang diinginkan menandai semua jenis disiplin yang otoriter. Tekniknya mencakup hukuman yang berat bila terjadi kegagalan memenuhi standar dan sedikit, atau sama sekali tidak ada persetujuan, pujian dan tanda-tanda penghargaan lainnya bila anak memenuhi standar yang diharapkan. Disiplin otoriter dapat berkisar antara pengendalian perilaku anak yang wajar hingga yang kaku yang memberi kebebasan bertindak, kecuali yang sesuai dengan standar yang ditentukan. Disiplin otoriter selalu berarti mengendalikan melalui kekuatan ekternal dalam bentuk hukuman, terutama hukuman badan.

Bahkan setelah anak bertambah besar, orang tua yang menggunakan pengendalian otoriter yang kaku jarang mengendurkan pengendalian mereka atau menghilangkan hokuman badan. Mereka tidak mendorong anak untuk dengan mandiri mengambil keputusan-keputusan yang berhubungan dengan tindakan mereka. Sebaliknya, mereka hanya mengatakan apa yang harus dilakukan, dan tidak menjelaskan mengapa hal itu harus dilakukan. Jadi anak-anak kehilangan kesempatan untuk belajar bagaimana mengendalikan perilaku mereka sendiri. Dalam keluarga dengan cara mendisiplin otoriter yang wajar, anak tetap dibatasi dalam tindakan mereka, dan keputusan-keputusan diambil oleh orang tua. Namun keinginan mereka tidak seluruhnya diabaikan, misalnya larangan melakukan apa yang dilakukan teman sebaya berkurang. 
2. Pola Demokrasi.

Metode demokrasi menggunakan penjelasan, diskusi dan penalaran untuk membantu anak mengerti mengapa perilaku tertentu diharapkan. Metode ini lebih menekankan aspek edukatif dari disiplin dari pada aspek hukumannya.

Bila anak masih kecil, mereka diberi penjelasan mengenai peraturan yang harus dipatuhi dalam kata-kata yang dapat dimengerti. Misalnya, bila ada peraturan bahwa mereka tidak boleh menyentuh kompor di dapur, mereka diberi tahu bahwa perbuatan tersebut akan menyakiti mereka, atau diperlihatkan, dengan mendekatkan tangan mereka pada kompor, arti kata sakit dan mengapa mereka tidak boleh menyentuh kompor. Dengan bertambahnya usia, mereka tidak saja diberi penjelasan tentang peraturan, melainkan juga mereka diberi kesempatan untuk menyatakan pendapatnya tentang peraturan.

Disiplin demokratis menggunakan hukuman dan penghargaan, dengan penekanan yang lebih besar pada penghargaan. Hukuman tidak pernah keras dan biasanya tidak berbentuk hukuman badan. Hukuman digunakan bila terdapat bukti bahwa anak-anak secara sadar menolak melakukan apa yang diharapkan dari mereka. Bila perilaku anak memenuhi standar yang diharapkan, orang tua yang demokratis akan menghargainya dengan pujian atau pernyataan persetujuan yang lain.

3. Pola Permisif

Disiplin permisif sebetulnya berarti sedikit disiplin atau tidak berdisiplin. Biasanya disiplin permisif tidak membimbing anak ke pola perilaku yang disetujui secara sosial dan tidak menggunakan hukuman. Beberapa orang tua dan guru, yang menganggap kebebasan (permissivness) sama dengan laissezfaire, membiarkan anak-anak meraba-raba dalam situasi yang terlalu sulit untuk ditanggulangi oleh mereka sendiri tanpa bimbingan atau pengendalian.

Bagi banyak orang tua, disiplin permisif merupakan protes terhadap disiplin yang kaku dan keras sama anak-anak mereka sendiri. Dalam hal ini, seperti anak sering tidak diberi batas-batas atau kendala yang mengatur apa saja yang boleh dilakukan; mereka dijanjikan untuk mengambil keputusan sendiri dan berbuat sekehendak mereka sendiri.

Dalam pandangan penulis pola-pola di atas memiliki kelebihan dan kelemahan dalam pembentukan kedisiplinan anak. Anak yang dibentuk dengan pola otoriter biasanya memiliki kedisiplinan yang tinggi akan tetapi kedisiplinan itu bukan datang dari kesadaran dirinya. Anak yang dibentuk dengan pola permisif kedisiplinannya terbentuk secara sadar dari hasil belajar senndiri terhadap lingkungan melalui trail and error, akan tetapi terbentuknya kedisiplinan biasanya sangat lama karena tidak ada yang mengarahkan. Sementara anak yang dibentuk dengan pola kedisiplinan demokrasi biasanya memiliki kedisiplinan yang tinggi dan kedisiplinan yang dimilikinya berasal dari kesadaran mereka karena mereka dibimbing dengan menggunakan penjelasan dan diskusi-diskusi yang logis tentang perlunya berdisiplin. 
Dalam pandangan penulis pola yang baik dalam pembentukan disiplin anak adalah dengan menggabungkan ketiga pola diatas karena pada dasarnya tiap pola itu sama-sama memiliki kelebihan dan kekurangan. Maka dengan menggabungkan ketiga pola diatas orang tua dan pendidik memiliki pilihan pola mana yang terbaik untuk diterapkan pada saat tertentu dan kapan pola tersebut tidak tepat dilakukan.

Pada saat-saat tertentu seorang anak perlu diberi ketegasan untuk berdisiplin tanpa kompromi seperti kedisiplinan menjalankan shalat lima waktu. Pada saat yang lain seorang anak perlu diajak berdiskusi untuk membahas bagaimana berdisiplin dalam menata kamar, dan rutinitas sehari-hari. Dan pada saat yang lain seorang anak perlu diberi kebebasan untuk belajar sendiri tentang pola-pola kedisiplinan orang lain agar ia dapat memahami dengan kesadarannya sendiri.

\section{Penutup}

Berdasarkan uraian diatas dapat disimpulkan bahwa pola-pola pengembangan keberbakatan dan pembentukan kedisiplinan anak yang efektif adalah yang didasarkan pada polapola perkembangan anak. Dengan berlandaskan pada pola-pola perkembangan orang tua dan para pendidik dapat mengetahui kemampuan apa saja yang telah dimiliki dan kemampuan apa saja yang dapat diharapkan telah dimiliki anak pada usia tertentu. Dengan berlandaskan pada perkembangan anak maka orang tua dan pendidik mampu mengenali dengan baik kapan seorang anak telah me- ngerti arti dan pentingnya disiplin bagi dirinya sendiri dan bagi orang lain.

Adapun kondisi-kondisi yang perlu diperhatikan dalam pengembangan keberbakatan anak adalah kondisi psikologis anak, kondisi lingkungan, dan kondisi orang tua serta pendidik. Sementara pola pembentukan kedisiplinan anak yang baik adalah yang memadukan antara pola otoriter, pola demokrasi, dan pola permisif.

\section{Daftar Pustaka}

Dryden, G. \& Vos, J. (2002). Revolusi Cara Belajar. Bandung: Kaifa

Fakultas Tarbiyah IAIN Sunan Gunung Djati Bandung. (2002). Media Pendidikan Jurnal Pendidikan Keagamaan. Bandung.

Habibie, Z. (2003). Hubungan Antara Kedisiplinan Dalam Menjalankan Shalat Lima Waktu Dengan Self Control Pada Siswa Madrasah Aliyah Cipari Wanaraja Garut. Skripsi

Hall, C S \& Linzdzey, G. (1993). Teori-Teori Pssikodinamik (Klinis). Yogyakarta: Kanisuis

Haricahyono, C. (1995). Dimen-Dimensi Pendidikan Moral. Semarang: IKIP Press.

Howard, G. (2003). Kecerdasan Majemuk Teori Dalam Praktek. Batam: Interaksa.

Hurlock, E B. (1978). Psikologi Perkembangan Anak. jilid 1 edisi keenam. Jakarta: Erlangga.

Hurlock, E B. (1978). Psikologi Perkembangan Anak. jilid 2 edisi keenam. Jakarta: Erlangga.

Hurlock, E B. (1980). Psikologi Perkembangan Suatu Pendekatan Sepanjang Rentang Kehidupan. edisi kelima. Jakarta: Erlangga.

Kohlberg, L. (1994). Tahap-Tahap Perkembangan Moral. Yogyakarta: Kanisius.

Meiner, D. (2002). The Accelerated Learning. Bandung: Kaifa 
Psympathic, 2009, Vol. I, No.1: 39 - 50

Rose, C \& Nicholl, M J. (2002). Accelerated Learning Carabelajar Cepar Abad XXI. Bandung: Nuansa

Syah, M. (2003). Psikologi Belajar. Jakarta: Raja Grafindo Persada. 